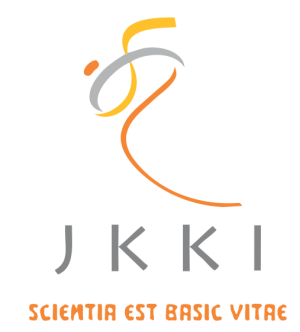

Jurnal Kedokteran dan Kesehatan Indonesia

Indonesian Journal of Medicine and Health

Journal homepage: https://journal.uii.ac.id/JKKI

\title{
Nutritional profile in Indonesian elderly subpopulation
}

Deasy Irawati ${ }^{1 *}$, Ardiana Ekawanti ${ }^{2}$, Anom Josafat $^{1}$

${ }^{1}$ Department of Public Health, Faculty of Medicine, Universitas Mataram, Mataram, Indonesia

${ }^{2}$ Department of Biochemistry, Faculty of Medicine, Universitas Mataram, Mataram, Indonesia

\begin{tabular}{l}
\hline \\
\hline ART ICLE I NF O \\
\hline Keywords: \\
Malnutrition, \\
elderly, \\
macronutrient, \\
micronutrient \\
*Corresponding author: \\
deasy.irawati@unram.ac.id \\
\hline DOI: 10.20885/JKKI.Vol11.Iss2.art4 \\
History: \\
Received: October 10, 2019 \\
Accepted: August 25, 2020 \\
Online: August 31, 2020 \\
\hline Copyright @2020 Authors. \\
This is an open access article \\
distributed under the terms \\
of the Creative Commons At- \\
tribution-NonCommercial 4.0 \\
International Licence (http:// \\
creativecommons.org/licences/ \\
by-nc/4.0/).
\end{tabular}

Original Article

\section{ABSTRACT}

Background: Data on malnutrition in the developing countries showed that 1-3 elderly in every 5 elderly were malnourished. However, the data in Indonesia were limited. Malnutrition in elderly is often underdiagnosed and thus it usually goes undetected at earlier stage.

Objective: The aim of this study was to examine nutritional profile of elderly by using several indicators: anthropometry, Mini Nutritional Assessment (MNA) Questionnaire, and dietary intake.

Methods: A cross-sectional study was conducted among community dwelling elderly (aged $\geq 60$ years) and elderly in the institutional care. The outcome variables were prevalency of malnutrition (undernutrition and overnutrition) and macro and micronutrient intake. Nutrition profiles were assessed using anthropometry, MNA and 24-hour food recalls. Comparative analysis between continuous variables was conducted using Mann-Whitney or ANOVA. Differences between categorical variables were assessed using Chi-square tests or Fisher's exact test.

Results: Based on BMI, in total, 1 in 2 elderly was either undernutrition or overnutrition. Based on MNA, 1 in 2 elderly were malnourished or at risk of malnutrition. Place of residency and gender were associated with the distribution of malnutrition in elderly $(\mathrm{p}<0.001)$. Approximately 1 in 2 elderly from the community dwelling group were overweight and obese whereas 1 in 3 elderly from the institutional care group were severely thin and thin. The intakes of 4 in 5 elderly were deficient in vitamin D, calcium, vitamin $\mathrm{E}$ and folate.

Conclusion: Elderly in our population group were experiencing the double burden of malnutrition and this coexisted with micronutrient deficiency.

Latar Belakang: Data tentang malnutrisi di negara berkembang menunjukkan bahwa 1-3 lansia dari setiap 5 lansia mengalami malnutrisi. Namun, data mengenai hal ini di Indonesia masih terbatas. Malnutrisi pada lansia seringkali tidak terdiagnosis dan tidak terdeteksi pada tahap awal malnutrisi.

Tujuan: Tujuan dari penelitian ini adalah untuk mengetahui profil gizi pada lansia dengan menggunakan beberapa indikator yakni antropometri, kuesioner Mini Nutritional Assessment (MNA) dan asupan gizi.

Metode: Penelitian potong lintang ini dilaksanakan pada lansia (usia $\geq 60$ tahun) yang tinggal di masyarakat dan lansia yang tinggal di panti sosial yang dikelola oleh pemerintah. Variabel utama dari penelitian ini adalah prevalensi malnutrisi (kekurangan gizi dan kelebihan gizi) dan asupan makronutrien serta mikronutrien. Profil gizi dinilai dengan pemeriksaan antropometri, MNA dan 24-hour food recalls. Analisis komparatif antar variabel kontinyu menggunakan Mann-Whitney atau ANOVA. Perbedaan proporsi antara variabel kategorikal dinilai dengan Chi-square tests atau Fisher's exact test.

Hasil: Berdasarkan indeks massa tubuh (IMT), 1 dari 2 lansia mengalami kekurangan gizi atau kelebihan gizi. Berdasarkan MNA, 1 dari 2 lansia tergolong malnutrisi atau memiliki resiko malnutrisi. Tempat tinggal 
dan jenis kelamin berhubungan dengan distribute malnutrisi pada lansia ( $p$ 0.001). Sebanyak 1 dari 2 lansia yang tinggal di masyarakat mengalami berat badan lebih dan obesitas sedangkan 1 dari 3 lansia yang tinggal di panti sosial tergolong sangat kurus dan kurus. Sebanyak 4 dari 5 lansia memiliki asupan vitamin $D$, kalsium, vitamin $E$ dan folat yang rendah. Kesimpulan: Lansia pada kelompok penelitian kami mengalami beban ganda malnutrisi dan hal ini diperparah dengan kekurangan asupan mikronutrien.

\section{INTRODUCTION}

The life expectancies are increasing worldwide. In Indonesia alone, it is estimated that the proportion of elderly would be doubled and 1 in 5 Indonesians will be categorized as elderly by the year $2050 .{ }^{1}$ The increased number of aging population will have an impact on the increased prevalence of chronic diseases and thus will add the burden on health care cost and resource utilization. In 2015, data on the dependency ratio in Indonesia indicated that 1 economically active individual had to support and provide social service needed by 2 children and/ or elderly. ${ }^{2}$ This economical burden is expected to increase with the longer life expectancies.

Elderly individuals are susceptible to malnutrition due to physiological changes related to aging and limitation in accessing healthy nutritious meals (purchasing and preparing food by themselves). ${ }^{3}$ It is a common assumption that malnutrition in developing country is associated with undernutrition due to food insecurity. However, nutrition transition and lack of dietary diversity lead to heightened prevalence of overnutrition. ${ }^{4}$ It is well recognized that middle income countries are experiencing a double burden of overnutrition related issues (overweight-obesity and non-communicable disease) alongside the undernutrition issues. Nutritional transition from diet high in carbohydrate towards diet high in fats is one of the factors contributing to the double burden of malnutrition. ${ }^{4,5}$ This feature has been reported recently. In Libanon, $8 \%$ of the subjects were undernutrition, $29.1 \%$ were at risk of undernutrition and $68.1 \%$ elderly were overweight/obesity. ${ }^{6}$ In India, the prevalence of undernutrition was $24.7 \%$ and overweight/obesity was $37.6 \%{ }^{7}$ In Iran, $12 \%$ were malnourished, $45.3 \%$ were at risk of malnutrition and $42.7 \%$ were well nourished. ${ }^{8}$ It is expected that the shift from undernutrition to overnutrition would be more prominent in the future.

Despite malnutrition in the elderly is emerging, data about malnutrition in Indonesian health registry (RISKESDAS) still focused on population age less than 5 years old and adults within the reproductive age. Setiati et al reported that $17.6 \%$ elderly were at risk of malnutrition and $5.2 \%$ were classified as malnourished. ${ }^{9}$ However, this study was conducted in 13 hospitals in Indonesia suggesting that the study population may have been subjected to heightened risk of malnutrition related diseases and thus may over-estimate the risk of malnutrition in the general population. The aim of this study was to examine nutritional profile of elderly. In this study, we targeted elderly living freely in the community and elderly in the institutional care.

\section{METHODS Population and sample}

The study was conducted in 2017 in West Nusa Tenggara, Indonesia. Participants were recruited consecutively from community dwelling elderly and/or elderly residing in the government institutional care at least 6 months in Mataram City. The inclusion criteria were elderly aged 60 years or more and agreed to participate in the study. Elderly who were unable to be measured for weight and height on standing position were excluded from the study. A sample size of 80 elderly in total was determined from malnutrition proportion in Kalaiselvi et al with $\alpha$ of 0.05 and power $80 \% .^{7}$ The study has been approved by Ethics Committee of Faculty of Medicine Mataram University (ethics number: 149/UN18.8/ETIK/2017). The objective and the protocol of the study were clearly explained to the participants. All participants provided signed informed consent prior to enrolment. Subjects, who could not speak in Bahasa, were guided by 
a local language interpreter to answer questions.

\section{Study protocol}

Following enrolment, participants were personally interviewed to collect data on age, medical history, psychosocial factors, MNA questionnaire and International Physical Activity Questionnaires (IPAQ). Anthropometric data was also collected.

\section{Anthropometrics}

Anthropometric and clinical examinations were conducted in the clinical room in the Tresna Werdha Puspakarma institutional care. Upon arrival, participants were measured for body weight, height, waist circumference, mid upper arm circumference, triceps skinfold thickness, and calf circumference. Body weight was measured with participants wearing limited clothing on a digital balance and recorded to the nearest 100 g. Standing height was measured using a microtoise fixed to the wall, without shoes and recorded to the nearest $0.1 \mathrm{~cm}$. Calf circumference, mid upper arm circumference and waist circumference were assessed using a tape, measured to the nearest $0.5 \mathrm{~cm}$. The measurement of triceps skinfold was performed on the left side using a thickness calliper. Methods of measurement were based on guidelines from WHO. ${ }^{10}$ Waist circumference was measured as described by WHO ${ }^{11}$ The measurements were conducted in duplicates.

\section{Screening for malnutrition}

Participants were screened for malnutrition using BMI classification and Mini Nutritional Assessment (MNA). BMI was categorized according to Indonesian nutritional status classification (Permenkes No 41 tahun 2014): severe thinnes (BMI $<17 \mathrm{~kg} / \mathrm{m}^{2}$ ), thin (BMI $17<18.5 \mathrm{~kg}$ ), normal weight (BMI 18.5-25.0 $\mathrm{kg} / \mathrm{m}^{2}$ ), overweight (BMI $>25.0-27.0 \mathrm{~kg} / \mathrm{m}^{2}$ ) and obese (BMI $>27.0 \mathrm{~kg} / \mathrm{m}^{2}$ ). The Indonesian classification of nutritional status was modified from WHO ${ }^{10}$ Abdominal obesity was defined as waist circumference $\geq 90 \mathrm{~cm}$ for men and $\geq 80 \mathrm{~cm}$ for women in Asian population. ${ }^{12}$ Using
MNA, malnutrition was defined as MNA score < 17 , at risk of malnutrition with MNA score 17 -23.5 and normal when MNA score $\geq 24$ point. (13) Dietary intakes of 2 days in the weekday were collected using 24-hours food recall. The interview was conducted by a trained nutrition enumerator and the data was analyzed using Nutrisurvey software adopting Indonesian food data base.

\section{Statistical analysis}

Data were analyzed using IBM SPSS software package version 17 (SPSS Inc., Chicago, USA). The results are all presented in the tables as mean values and standard error (SE) for continuous variables and proportion for categorical variables or in figures. Differences between 2 continuous variables were assessed using independent $t$-test or Mann-Whitney as appropriate. Comparison between 3 or more continous variabels were conducted using ANOVA or Welch ANOVA as appropriate. Differences between categorical variables were assessed using Chi-square tests or Fisher's exact test as appropriate. A p value $<0.05$ was considered significant.

\section{RESULTS}

A total of 83 elderly (71\% women) took part in the study. The mean age of the study population was 69 (SE 0.7) years (Table 1). Two-third of the elderly were categorized as central obesity. The prevalence of central obesity was higher in the community dwelling group compared to those in the institutional care group $(\mathrm{p}<0.01)$. This pattern was also observed in other anthropometrics parameters: body mass index, triceps skinfold thickness, mid upper arm circumference, waist circumference and calf circumference.

In total, 1 in 2 elderly were either undernutrition or overnutrition with the details as follow: $5.1 \%$ of elderly were severely thin, $10.3 \%$ were thin, $48.7 \%$ were normal, $10.3 \%$ were overweight and $25.6 \%$ were obese. The distribution of nutritional status between elderly living freely and elderly in the institutional care differed significantly $(\mathrm{p}<0.001)$ (Figure 1$)$. 
Based on BMI, 1 in 3 elderly in the institutional care were thin to severely thin whereas 1 in 2 elderly in the community dwelling group were overweight to obese.

Table 1. Data of blood pressure

\begin{tabular}{|c|c|c|c|c|c|c|}
\hline \multirow[t]{2}{*}{ Parameters } & \multicolumn{2}{|c|}{ Total } & \multicolumn{2}{|c|}{$\begin{array}{c}\text { Community } \\
\text { dwelling }(n=47)\end{array}$} & \multicolumn{2}{|c|}{$\begin{array}{c}\text { Institutional care } \\
(n=36)\end{array}$} \\
\hline & Mean/\% & SE & Mean/\% & SE & Mean $/ \%$ & SE \\
\hline Men/women (\%) & $29 / 71$ & & & & & \\
\hline Age (years) & 69 & 0.7 & & & & \\
\hline BMI (kg/m2) & 23.4 & 0.5 & 24.9 & 0.6 & $21.1^{* * 1}$ & 0.7 \\
\hline Triceps skinfold thickness (mm) & 29.5 & 1.2 & 32.9 & 1.5 & $25.0^{* * 1}$ & 1.6 \\
\hline Mid upper arm circumference $(\mathrm{cm})$ & 28.8 & 0.5 & 30.7 & 0.6 & $26.3^{* * 1}$ & 0.7 \\
\hline Waist circumference $(\mathrm{cm})$ & 88.8 & 1.4 & 92.6 & 1.7 & $83.8^{* * 1}$ & 2.0 \\
\hline Calf circumference $(\mathrm{cm})$ & 31.9 & 0.6 & 34.4 & 0.5 & $28.7^{* * 1}$ & 0.9 \\
\hline Central obesity (\%) & 60.2 & & 83 & & $34^{* * 2}$ & \\
\hline
\end{tabular}

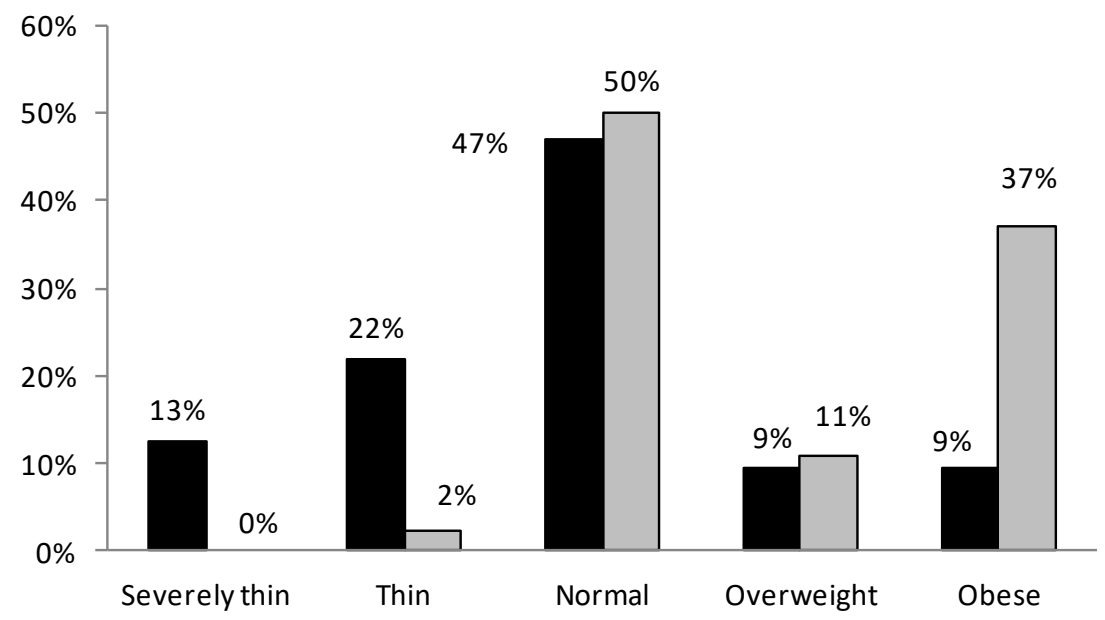

Figure 1. Distribution of elderly according to nutritional status based on BMI between institutional care group (black bars) and community dwelling group (grey bars).

In both community dwelling and institutional care groups, the majority of participants were women $(76.6 \%$ in community dwelling and $63.9 \%$ in institutional care facilities). Central obesity were more prevalent in elderly women compared to elderly men $(69.7 \%$ in women versus $30 \%$ in men, $\mathrm{p}<0.001$ ). Elderly women tend to have a higher BMI than those in elderly men $(24 \mathrm{~kg} / \mathrm{m} 2$ in women versus $21.8 \mathrm{~kg} / \mathrm{m} 2$ in men, $\mathrm{p}=0.063$ ). Similar trends were also observed in triceps skinfold thickness (30.9 $\mathrm{mm}$ in women versus $26.1 \mathrm{~mm}$ in men, $\mathrm{p}=0.051$ ). No significant differences in calf circumference and middle upper arm circumference between genders were observed.

When the data were stratified according to age group (60-69 year, 70-79 years and 80 years or more), the majority of community dwelling elderly were $60-69$ years old $(72.3 \%)$, whereas $58.3 \%$ elderly in institutional care 
facility were 70 years old or more. With the increase in age, the prevalence of central obesity decreased $(p=0.002)$. Older elderly age group subjects presented lower BMI ( $\mathrm{p}=0.007)$, waist circumference $(p=0.006)$, calf circumference $(\mathrm{p}=0.008)$, mid upper arm circumference $(p<0.001)$ and triceps skinfold thickness $(p=0.003)$ than those in the younger elderly age group.

Based on MNA classification, $2.9 \%$ of subjects were malnourished, $52.9 \%$ were at risk of malnutrition and $44.3 \%$ were well-nourished.
The risk of malnutrition was significantly higher in the institutional care group compared to those in the community dwelling group $(p<0.001)$. All malnourished subjects and 62\% of subjects at risk of malnutrition were from the institutional care group. Decrease in dietary intake contributed to the malnutrition status $(p=0.019)$. Approximately $50 \%$ of malnourished elderly reported having a decrease in dietary intake. Around $94 \%$ of well-nourished elderly had sufficient dietary intake.

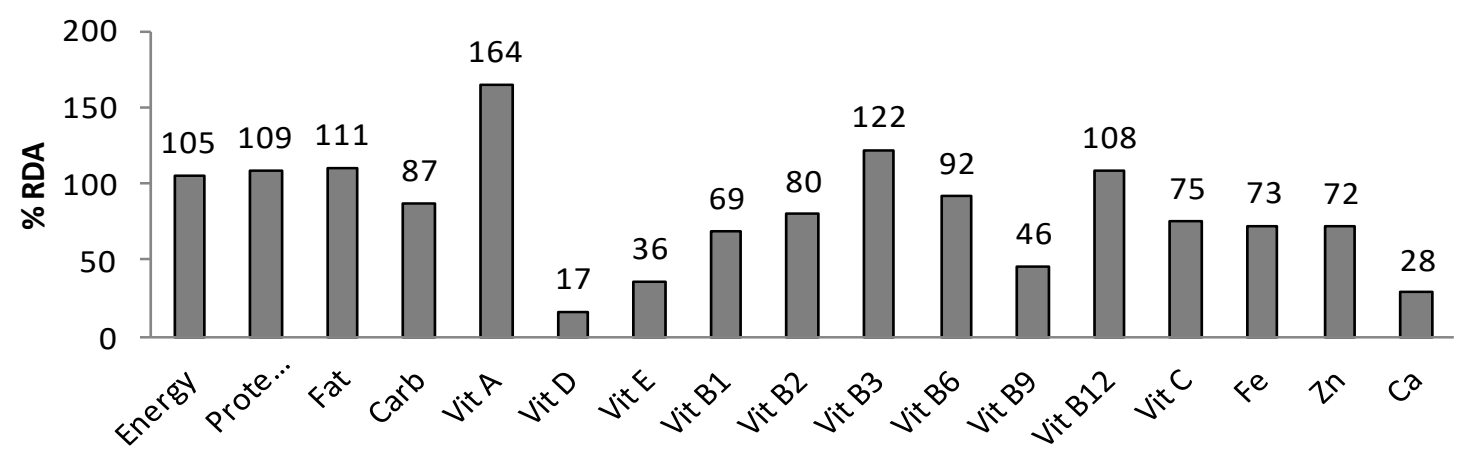

Figure 2. Median percentage RDA of macro- and micronutrient

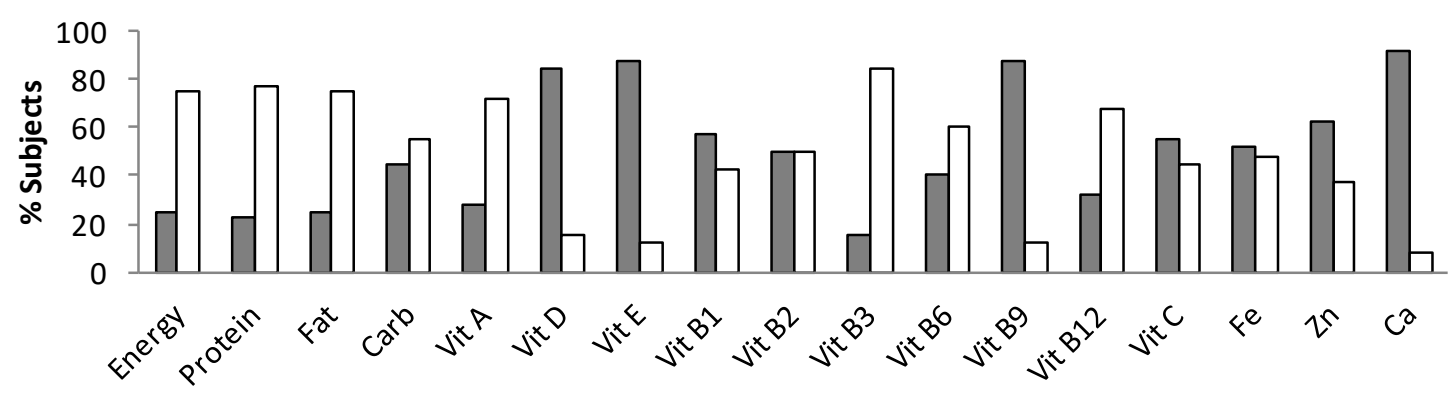

Figure 3. Percentage of subjects having $<80 \%$ RDA (grey bars) dan AKG $\geq 80 \%$ (white bars) of each nutrient.

Based on 24-hours food recalls data, dietary intake of macronutrients ranged between $85 \%-110 \%$ RDA (Figure 2). The majority of micronutrient intake were more than 70\% RDA except intake of vitamin D (17\% RDA), calsium (28\% RDA), vitamin E (36\% RDA), and folate (46\% RDA). Intake of vitamin A was more than

\section{0\% RDA.}

Percentage of subjects having $<80 \%$ RDA and $\geq 80 \%$ RDA of each nutrient can be seen in Figure 3 . The majority of subjects consumed $\geq 80 \%$ RDA of macronutrient, vitamin A, and niacin. More than $80 \%$ of the subjects consumed $<80 \%$ RDA of vitamin D, vitamin E, folate, and calcium. 


\section{DISCUSSION}

This study explored the risk for malnutrition in elderly. The main finding of this study was the high prevalent of overnutrition coexisting with undernutrition and micronutrient deficiency in elderly. In the present study, participants in the community dwelling group and those in the institutional care were screened for undernutrition and overnutrition. The results showed that the distribution of form of malnutrition varied according to the place of residency. The prevalence of overweight/ obesity were higher in the elderly from the community dwelling group compared to those in the institutional care. In contrast, undernutrition was prevalent in the elderly from the institutional care group. This is in line with the finding of Guigoz et al reporting that undernutrition in elderly in the institutional care were much higher (37\%) than those in the community dwelling population group (1\%). ${ }^{14}$ When we analysed further, the majority of elderly residing in the institutional care facility were 70 years old or more. Their BMI and other anthropometric parameters were lower than those of the younger age group. Similar findings were also reported by a large cross-sectional anthropometric study in Italy involving 3356 elderly. ${ }^{15}$ They demonstrated a decreased BMI with age in both genders.

We found that 1 in 3 overall elderly were overweight/obese and 2 in 3 elderly women were centrally obese indicating accumulation of fat in visceral sites. The calf circumference and the middle upper arm circumference of elderly in the older age group were lower than that of the younger age group. In addition, elderly residing in the institutional care also exhibited lesser muscle mass than that of the community dwelling group. These findings are in accordance with the finding of Kim et al. They reported loss of muscle mass and centralization of body fat during aging in a prospective study among Korean adults with follow-up of 27 months. ${ }^{16}$ Calf circumference and middle upper arm circumference have been suggested by World Health Organization (WHO) as indirect estimation of muscle mass. Calf circumference was used commonly than diagnostic imaging such as dual-energy X-ray absorptiometry (DXA) or computed tomography (CT) scan particularly in primary care facilities. ${ }^{10,17}$

Based on Indonesian Health Ministry guidelines for elderly health care, elderly will be screened for malnutrition using MNA short version (MNA-SV) and assessed using MNA long version (MNA-LV) ${ }^{18}$ Those with MNA-SV score of less than 11 will be assessed further with MNA-LV. Elderly who scored $<17$ (malnourished) in their final assessment will be referred to the referral hospital. Those who were at risk of malnutrition or having BMI of $25 \mathrm{~kg} / \mathrm{m}^{2}$ or more will undergo dietary intervention in the primary health care and their nutritional status will be evaluated periodically.

The present study showed that 1 in 2 elderly was either malnourished or at risk of malnutrition. All malnourished elderly and 2 in 3 elderly at risk of malnutrition were from the institutional care group. The low MNA score (i.e. malnourished or at risk of malnutrition) observed in our study was associated with dietary intake. Our result was in accordance with the finding of Lahiri et al stating that decrease in dietary intake could double the risk to develop malnutrition..$^{19}$ Difficulty in chewing and digesting food, preparing meals and finishing a portion size of meal contributed to the heightened of undernutrition prevalence in elderly. ${ }^{20,21}$

Micronutrient deficiency often coexists with malnutrition, regardless under or overnutrition. Low intake of micronutrient has been reported both in developing and developed countries. A meta-analysis study on micronutrient intake in the developing countries including South East Asia region demonstrated that low intake of iron, folate and zinc were prevalent. ${ }^{22}$ In developed countries, older adults were susceptible to low intake of thiamine, riboflavine, vitamin D, calcium, magnesium and selenium. ${ }^{23}$

In the present study, 4 in 5 elderly were having low intake of vitamin D, calcium, vitamin $\mathrm{E}$ and folate whereas the dietary intake of macronutrients ranged between 85\%- 110\% 
RDA. The findings of the present study were slightly different with the findings of Setiati et al. They reported that the dietary intake of calcium, protein and energy in their elderly population group were below its RDA level. ${ }^{9}$ This could be due to different characteristics of the subjects. Their study was performed in hospitalized elderly patients in Indonesia whilst the subjects of our study were relatively healthy elderly either residing in an institutional care or living with their families.

Inadequacy of dietary intake in elderly could be due to limited choice of food that is digestible for elderly, aging process (chewing, digesting), motoric limitation and difficulty in preparing healthy meals (e.g. cooking on their own and purchasing food).$^{24}$ Elderly often adjusted their dietary menu with their motoric and cognitive ability leading to monotonous diets or low dietary diversity. The rare availability of highly nutritious food source may also affect dietary intake. For example, the availability of food source rich in vitamin D is scarce. ${ }^{25}$ Most of the source of vitamin D are from endogenous vitamin D synthesized in the skin or from supplements. ${ }^{26}$ Other factors such as bioavailability and social economics were also contributing to the low dietary intake in elderly. ${ }^{27,28}$

Interestingly, we found high prevalent of high intake of vitamin A among elderly in our population group. However confirmation with biomarker examination is needed. To increase dietary intake, one may consume supplements (vitamin, minerals) or through health promotion on how to retain micronutrient in food processing especially nutrients that were sensitive to heat and water soluble.

Shift in the distribution of undernutrition to overnutrition in the community is commonly experienced by developing/middle income countries where economic and health development increased rapidly. In Indonesia, North Sumatra, West Java, East Java, North and Central Sulawesi, Halmahera and Papua were districts with high prevalence of overnutrition whereas South Sumatra, Central Kalimantan, South Kalimantan, northern part of Java and Nusa
Tenggara islands were cluster of districts with prevalent undernutrition. ${ }^{29}$ Indramayu in West Java and Fak Fak in West Papua were the only districts where undernutrition and overnutrition coexisted within the same districts. Our findings have shown the potential double burden of malnutrition in Nusa Tenggara, districts where previously undernutrition was prevalent. Further study mapping double burden of malnutrition in Indonesia using the most recent nutritional survey is warranted. In terms of population subgroups, elderly were susceptible to double burden of malnutrition due to aging, decreased physical activity, psychological challenge and culture. ${ }^{30}$

The limitations of the present study are the relatively small sample size which may limit the power for subgroup analysis, and the unbalanced gender distributions between groups. In the present study, we did not examine supplement consumption, cognitive function and depression. Elderly living in the institutional care were more susceptible to depression. It has been reported that the prevalence of depression rose up to $45 \%$ in elderly living in the institutional care, a 3-4 times greater than that of the community dwelling elderly. ${ }^{13,31,32}$ We have assessed the physical activity level using IPAQ however the variation of the result was very high. Finally, the cross-sectional design of this study cannot determine the causation between variables. The strength of our study is that our population groups include community dwelling elderly as they are part of the general population.

\section{CONCLUSION}

In conclusion, elderly in our population group were experiencing the double burden of malnutrition and this coexisted with micronutrient deficiency. Dietary intake of vitamin $\mathrm{D}$, calcium, vitamin $\mathrm{E}$ and folate were very low whereas vitamin A intake was high. Since the proportion of aging society in Indonesia is predicted to increase, institutional care facilities for elderly may serve as pockets of undernutrition in elderly. Adequate screening program in place and promoting healthy aging 
awareness in families living with elderly are vital.

\section{CONFLICT OF INTEREST}

None

\section{ACKNOWLEDGEMENT}

We gratefully acknowledge the participants, Ms Priyanti, Ms Martina, the enumerators for their help in participant recruitments and Hepatica Laboratory. The work reported in this manuscript was supported by PNBP scheme research, Faculty of Medicine, Mataram University.

\section{AUTHOR CONTRIBUTIONS}

Conceived and designed the study: DI, AE and AJ. Performed the experiments: DI and AE. Analysed the data: DI and AJ. Wrote the manuscript: DI. Reviewed and critically revised the manuscript for important intellectual content: DI, AE and AJ. All authors approved the final version of the manuscript.

\section{REFERENCES}

1. UN-DESA. World Population Prospects: The 2015 revision, key findings and advance tables. 2015.

2. RI KK. Profil kesehatan Indonesia tahun 2015. 2016.

3. Agarwal E, Miller M, Yaxley A, Isenring E. Malnutrition in the elderly: A narrative review. Maturitas. 2013;76(4):296-302.

4. Ngaruiya C, Hayward A, Post L, Mowafi $\mathrm{H}$. Obesity as a form of malnutrition: Over-nutrition on the Uganda malnutrition agenda. The Pan African Medical Journal. 2017;28:49.

5. Popkin BM. The nutrition transition and its health implications in lower-income countries. Public Health Nutrition. 1998;1(1):521.

6. Boulos C, Salameh P, Barberger-Gateau P. The AMEL study, a cross sectional population-based survey on aging and malnutrition in 1200 elderly Lebanese living in rural settings: Protocol and sample characteristics. BMC Public Health. 2013;13(1):573.

7. Kalaiselvi S, Arjumand Y, Jayalakshmy R, Go- mathi R, Pruthu T, Palanivel C. Prevalence of under-nutrition, associated factors and perceived nutritional status among elderly in a rural area of Puducherry, South India. Archives of Gerontology and Geriatrics. 2016;65:156-60.

8. Aliabadi M, Kimiagar M, Ghayour-Mobarhan M, Shakeri MT, Nematy M, Ilaty AA, et al. Prevalence of malnutrition in free living elderly people in Iran: A cross-sectional study. Asia Pacific Journal of Clinical Nutrition. 2008;17(2):285-9.

9. Setiati S, Harimurti K, Dewiasty E, Istanti R, Mupangati YM, Ngestiningsih D, et al. Profile of food and nutrient intake among Indonesian elderly population and factors associated with energy intake: A multi-centre study. Acta Medica Indonesiana. 2013 Oct;45(4):265-74.

10. WHO. Physical status: The use of and interpretation of anthropometry, report of a WHO expert committee. Geneva; 1995.

11. WHO. Waist circumference and waist-hip ratio: Report of a WHO expert consultation. Geneva; 2011.

12. Alberti KGMM, Eckel RH, Grundy SM, Zimmet PZ, Cleeman JI, Donato KA, et al. Harmonizing the metabolic syndrome: A joint interim statement of the international diabetes federation task force on epidemiology and prevention; National heart, lung, and blood institute; American heart association; World heart federation; International atherosclerosis society; And international association for the study of obesity. Circulation. 2009;120(16):1640-5.

13. John BK, Bullock M, Brenner L, McGaw C, Scolapio JS. Nutrition in the elderly. frequently asked questions. American Journal of Gastroenterology. 2013;108(8):125266.

14. Guigoz Y, Lauque S, Vellas BJ. Identifying the elderly at risk for malnutrition. Clinics in Geriatric Medicine. 2002; 18(4):737-57.

15. Perissinotto E, Pisent C, Sergi G, Grigoletto F. Anthropometric measurements in the elderly: Age and gender differences. British Journal of Nutrition. 2002;87(2):177-86.

16. Kim TN, Park MS, Ryu JY, Choi HY, Hong 
$\mathrm{HC}$, Yoo HJ, et al. Impact of visceral fat on skeletal muscle mass and vice versa in a prospective cohort study: The Korean Sarcopenic Obesity Study (KSOS). PLoS ONE. 2014;9(12):e115407.

17. Bruye're O, Beaudart C, Reginster JY, Buckinx F, Schoene D, Hirani V, et al. Assessment of muscle mass, muscle strength and physical performance in clinical practice: An international survey. European Geriatric Medicine. 2016;7(3):243-6.

18. RI K. Penyelenggaraan Pelayanan Kesehatan Lanjut Usia di Pusat Kesehatan Masyarakat. Jakarta: RI, Kemenkes; 2017.

19. Lahiri S, Biswas A, Santra S, Lahiri SK. Assessment of nutritional status among elderly population in a rural area of West Bengal, India. International Journal of Medical Science and Public Health. 2015;4(4):569.

20. Soini H, Routasalo P, Lagstrom H. Characteristics of the Mini-Nutritional Assessment in elderly home-care patients. European Journal of Clinical Nutrtition. 2004 ;58(1):64-70.

21. Feldblum I, German L, Castel H, Harman-Boehm I, Bilenko N, Eisinger M, et al. Characteristics of undernourished older medical patients and the identification of predictors for undernutrition status. Nutrition Journal. 2007;6:37.

22. Torheim LE, Ferguson EL, Penrose K, Arimond $\mathrm{M}$. Women in resource-poor settings are at risk of inadequate intakes of multiple micronutrients. The Journal of Nutrition. 2010;140(11):2051S-8S.

23. ter Borg S, Verlaan S, Hemsworth J, Mijnarends DM, Schols JM, Luiking YC, et al. Micronutrient intakes and potential inadequacies of community-dwelling older adults: A systematic review. British Journal of Nutrition. 2015 Apr 28;113(8):1195206.

24. Bartali B, Salvini S, Turrini A, Lauretani F, Russo CR, Corsi AM, et al. Age and disability affect dietary intake. The Journal of Nutrition. 2003;133(9):2868-73.

25. Brouwer-Brolsma EM, Bischoff-Ferrari HA, Bouillon R, Feskens EJM, Gallagher CJ, Hypponen E, et al. Vitamin D: Do we get enough? Osteoporosis International. 2013;24(5):1567-77.

26. Brock KE, Ke L, Tseng M, Clemson L, Koo $\mathrm{FK}$, Jang $\mathrm{H}$, et al. Vitamin D status is associated with sun exposure, vitamin $\mathrm{D}$ and calcium intake, acculturation and attitudes in immigrant East Asian women living in Sydney. The Journal of Steroid Biochemistry and Molecular Biology. 2013;136:214-7.

27. Green R. Indicators for assessing folate and vitamin B-12 status and for monitoring the efficacy of intervention strategies. The American Journal of Clinical Nutrition. 2011;94(2):666S-72S.

28. McNulty H, Pentieva K. Folate bioavailability. Proceedings of the Nutrition Society. 2004;63(4):529-36.

29. Hanandita W, Tampubolon G. The double burden of malnutrition in Indonesia: Social determinants and geographical variations. SSM-Population Health. 2015;1(Supplement C):16-25.

30. Hickson M. Malnutrition and ageing. Postgraduate Medical Journal. 2006;82(963):28.

31. Jongenelis K, Pot AM, Eisses AM, Beekman AT, Kluiter H, Ribbe MW. Prevalence and risk indicators of depression in elderly nursing home patients: The AGED study. Journal of Affective Disorders. 2004;83(23):135-42.

32. Teresi J, Abrams R, Holmes D, Ramirez M, Eimicke J. Prevalence of depression and depression recognition in nursing homes. Social Psychiatry and Psychiatric Epidemiology. 2001;36(12):613-20. 